\title{
Amizades muito hierárquicas: direitos e emoções nas relações entre domésticas e patroas
}

Fábio de Medina da Silva Gomes

Universidade Federal Fluminense, Niterói, Rio de Janeiro, Brasil

DOI 10.11606/issn.2316-9133.v24i24p290-314

resumo No presente artigo utilizei o método de observação direta, visando entender os discursos sobre as emoçóes e o trabalho doméstico remunerado em Niterói, com atenção especial no papel do judiciário na administração de conflitos entre empregadores e trabalhadoras domésticas. $\mathrm{O}$ trabalho de campo realizado inclui observação de 37 audiências e entrevistas. Além das inter-relaçôes entre fato e norma, foi explorada a questão da dádiva-retribuição nesse tipo específico de contrato. Por fim, o campo trouxe questôes de gênero. Pretende-se, assim, buscar uma compreensão ampla sobre a retórica das emoçóes nesse tipo de relação na cidade de Niterói.

palavras-chave Domesticidade; Dádiva; Emoçóes; Justiça; Trabalho.

Extremely hierarchical friendships: rights and emotions in relations between housekeepers and female bosses

abstract In this article I used the direct observation method, in order to understand the discourse on emotions and paid domestic work in Niteroi, particularly with attention to the role of the judiciary in the administration of disputes between employers and domestic workers. The fieldwork includes observation of 37 audiences and interviews. In addition to the interrelations between fact and norm, it was explored the issue of return-gift in that particular type of contract. Finally, the field has brought up gender issues. It is intended, thus, to provide a comprehensive understanding of the rhetoric of emotions that kind of relationship in the city of Niteroi.

keywords Domesticity; Gift; Emotions; Judiciary; Work. 
O trabalho doméstico remunerado sofreu profundas modificaçōes nas últimas décadas (SAFFIOTI, 1978; FRAGA, 2010). Como a principal instituiçáo reguladora desse setor do mercado de trabalho tem sido o próprio Poder Judiciário, ${ }^{1}$ pretendi, então, durante minha dissertação de mestrado, ${ }^{2}$ compreender a administraçáo institucional do conflito entre patroas e domésticas, ${ }^{3}$ na cidade de Niterói, no estado do Rio de Janeiro.

Realizei pesquisa de campo, durante nove meses, entre os anos de 2013 e 2014. Assisti a 37 audiências em todas as Varas do Trabalho do município de Niterói, situado na Região Metropolitana do Rio de Janeiro. ${ }^{4}$ Visitei duas vezes os sindicatos laboral e patronal dessa categoria profissional em Niterói. As entrevistas com sindicalistas, em que pese a relevância de seus discursos, não foram aproveitadas neste artigo em favor de uma maior objetividade no desenvolvimento do tema. Além disso, efetuei entrevistas não estruturadas com nove patroas, treze domésticas, trinta advogados, sete juízes e dois sindicalistas.

Para tanto, estabeleci uma rotina. Eu me dirigia à uma das Varas do Trabalho de Niterói, situadas todas no mesmo prédio no centro do referido município. Lá chegando, estudava a pauta de audiências, afixada na parede. Tratava-se de um pequeno resumo das açóes que seriam julgadas naquele dia. A maioria dos processos era em face de pessoas jurídicas, como empresas ou bancos. Nessas pautas, eu buscava os processos em que o réu era uma pessoa física. Anotava o número do processo, entrava na sala de audiências, abria o processo e lia a sua peça inicial. Nesse documento, chamado pelos nativos de Inicial, constava a ocupação do trabalhador. Geralmente, essas ações contra uma pessoa física eram de empregadas domésticas. Assistia uma audiência sobre trabalho doméstico remunerado. Para além disso, também procurava outras três ou quatro audiências, na maioria das vezes em varas diferentes.

Como as audiências são públicas, não houve qualquer resistência a minha presença nas salas. Mesmo porque, não raramente, essas salas estavam cheias de gente sentada nas cadeiras e assistindo. Prosseguia tomando cuidado para não deixar de ir a nenhuma daquelas Varas. Passada a audiência, eu saia da sala e buscava a empregada doméstica ou a patroa para uma entrevista. Além disso, usava o tempo no trabalho de campo para me apresentar e conversar com advogados e juízes. Entendi como não sendo uma boa estratégia gravar algo naquele ambiente, marcado pelo conflito. Preferi anotar tudo num caderno de campo que sempre trazia comigo. Esforcei-me, desse modo, em compreender as diferentes percepçóes sobre essas relaçóes no espaço do Tribunal.

Durante essa pesquisa, utilizei o método da observaçáo direta, tendo sido influenciado, especialmente, por Gerald Berreman (1990). Este autor 
importou-se com um aspecto específico da interação social, sugerindo a abordagem dramática como um meio pelo qual os indivíduos controlam impressōes. Enfatizou a interaçáo social entre o pesquisador e os sujeitos do campo.

Sua pesquisa, no Himalaia, contribuiu com reflexóes sobre aspectos importantes da etnografia. De um lado, os nativos tentavam manter uma certa zona interior fora do alcance do antropólogo. Essa tensão entre cena e bastidores, como regióes distintas e separadas por barreiras de percepção, era notória em minha pesquisa. Havia os juízes, os advogados, as domésticas e as patroas, cada um deles atuando na tentativa de controlar as impressões demonstradas uns aos outros. A cena das audiências escondia os bastidores das tratativas entre advogados, patroas e domésticas.

Era simples identificar a cena nas audiências. A dificuldade estava em compreender os bastidores. Essa tarefa me custou tempo. Só comecei a compreendê-los após meses de entrevistas e visitas ao campo. Depois, pude explorar muitas questóes surgidas dessas observaçóes. Quis, naquele momento, como antes referido, demonstrar os discursos e as práticas sociais comuns entre os nativos da minha pesquisa.

No presente artigo, pretendi dar relevo aos discursos e práticas sobre as emoçóes entre patroas e empregadas domésticas. Para tal, num breve primeiro momento, enfatizei minha experiência com atendimentos interdisciplinares às empregadas domésticas, quando trabalhei no Centro de Referência de Mulheres da Maré (CRMM), órgão da Universidade Federal do Rio de Janeiro (UFRJ). Posteriormente, expus alguns dados construídos na minha dissertação de mestrado. Explorei os discursos sobre as emoções no trabalho doméstico remunerado tal como mencionados, especificamente, pelos nativos.

\section{Primeiros momentos}

O meu interesse de estudo pelo trabalho doméstico remunerado surgiu antes mesmo do mestrado. Assim que terminei a graduaçáo em Direito, busquei atuar em alguma área da defesa de Direitos Humanos. Trabalhei, na qualidade de bolsista, no Centro de Referência de Mulheres da Maré (CRMM), órgão voltado ao resgate da cidadania feminina no Complexo da Maré. ${ }^{5}$ Ele é fruto de articulaçóes entre a Universidade Federal do Rio de Janeiro (UFRJ) e o governo federal, no intuito de coibir e prevenir a violência contra a mulher.

Tratava-se de um pequeno prédio com dois andares e náo mais do que dez salas, situado no bairro da Vila do João. ${ }^{6}$ Nesse lugar, além de outras atividades com mulheres, oferecíamos àquela comunidade um local 
de atendimento interdisciplinar. Eu, como profissional de Direito, sempre atendia na companhia de um psicólogo ou de um assistente social.

Posteriormente, escolhi o tema da minha dissertação de mestrado. Estudei um assunto muito visto nesses atendimentos, o trabalho doméstico remunerado e a Justiça do Trabalho. A inspiração inicial da minha pesquisa foi orientada, sobretudo, por minhas experiências em diversos atendimentos, oficinas sociais e reunióes. Não raro atendia alguma mulher procurando ajuda porque "trabalhou em casa de família" e não recebeu "tudo o que deveria". Muitas não queriam "colocar a patroa na justiça”, uma vez que “eram quase da família”. Outras já tinham buscado advogados, procurado o judiciário, já tinham audiência marcada, mas pediam para conferir no site do Tribunal Regional do Trabalho alguns detalhes. Muitas não confiavam em seus advogados.

Vinham à minha mente várias questões sobre as quais eu não poderia refletir naquele momento de atendimento. As regras jurídicas não falam sobre sentimentos, "ser quase da família" era expressão usada pelas partes envolvidas e sem sinônimos entre os juristas. Os livros de direito não tratam sobre isso. Como se comportou essa mulher, empregada doméstica, diante da figura do juiz? O que a fez procurar a justiça, mesmo se sentindo "quase da família"? O judiciário possuí algum mecanismo especial para administrar esse tipo de conflito? Como foram as audiências nesses casos? Quais eram os papéis dos juízes, advogados e partes nesses processos? Eles falavam de emoções? Ou apenas de indenizações em dinheiro?

\section{Subjetividades múltiplas}

Dois anos após essas experiências, em janeiro de 2014, durante a pesquisa realizada no mestrado, presenciei uma audiência interessante. Tratou-se de uma doméstica que chamarei de Agrado, ${ }^{7}$ postulando em juízo em face de Huma. Como sempre, entraram, na sala de audiências, a patroa e a doméstica acompanhadas de seus advogados. Sentaram-se à mesa. O juiz percebeu que a patroa, Huma, estava acompanhada de uma criança. Ele resmungou: “Criança de colo!”. Huma levou uma testemunha, Manuela. Ela também dizia ter sido doméstica de Huma.

No início da audiência, tão logo elas se sentaram, o juiz perguntou para os advogados: "Tem acordo, doutores?". Ambos disseram não ter um acordo, por enquanto. $\mathrm{O}$ juiz insistiu, mas eles não pretendiam acordar, não naquele momento. Ele ouviu, então, uma testemunha, Manuela. $\mathrm{O}$ juiz fez algumas perguntas a essa mulher. Após, questionou se os advogados teriam algo mais a inquirir. Ambos disseram que não. Ele, então, fez uma proposta de acordo. Olhou para a Huma e seu advogado e disse: "Com 
essa testemunha, que náo sabe quando trabalhou, acho que podemos ver um acordo de mil e duzentos reais". Todos concordaram, menos Agrado. Ela disse um "não" tímido. O juiz olhou para o advogado, dizendo: "Dá uma orientação para sua cliente, porque você é mais instruído que ela". Ele deu "sua orientação" e Agrado aceitou o acordo. Em seguida discutiram quando e como dona Huma pagaria.

Depois da audiência, já na sala de espera, procurei Agrado ou Huma para uma conversa. Percebi não ser estratégico entrevistar as duas juntas, pois, além de estarem distantes, havia uma evidente animosidade. Conversei com Agrado já no corredor. Tratava-se de uma senhora baixinha, aparentando no máximo cinquenta anos. Aproveitei que seu advogado estava com ela, pois, quem sabe, ele daria alguma opinião.

[Eu:] - Oi. Desculpa incomodar a senhora e o seu advogado, mas meu nome é Fábio, sou um pesquisador da Universidade, aqui da UFF. Eu estou fazendo uma pesquisa sobre as empregadas domésticas no tribunal. A senhora teria um minutinho pra mim?

[Agrado:] - Tenho sim [ela disse, sorrindo. O que me tranquilizou, dada a possibilidade de ela dizer não].

[Eu:] - Bom, primeiro quero esclarecer que seu nome será mantido em sigilo. Queria saber como a senhora se sentia na casa em que trabalhou e como se sentiu aqui na justiça? [Agrado:] - Me senti humilhada aqui, ainda mais com aquela mulher mentindo lá (testemunha). Tinha muito tempo que eu trabalhava pra ela (Huma) e não esperava por isso. Mas antes disso, eu me dava bem com ela. A gente tinha uma relaçáo de confiança. Eu adoro a filhinha dela, ela tem dois anos, e fui eu que ajudei a criar. Será que eu consigo falar de novo com ela e com a filha dela [de Huma]? Eu queria tanto ver a criança... [Sua fala logo foi interrompida pelo seu advogado.]

[Advogado de Agrado:] - Mas agora que você fez o acordo, pode até ligar pra ela. Ela com certeza vai te receber bem.

[Eu:] - Vou fazer a minha última pergunta, para não atrapalhar mais. O que você buscava aqui?

[Agrado:] - Meus direitos, ué! [A resposta teve um tom de surpresa, como se a minha pergunta fosse a mais óbvia do mundo.]

Achei interessante a possibilidade de debater a dicotomia razão e emoção. Até que ponto a ação humana é orientada pela razão, somente? Voltando à 
cena do tribunal, me questiono. Huma, Manuela e Agrado agiram sobre qual motivação? A ação dessas mulheres no tribunal era guiada pela razão ou pela emoção? Pode-se dividir a vida entre esferas da razão e da emoção? O motivo de Agrado ter processado Huma é racional? É emocional? A doméstica diz que está buscando seus direitos. E, ao mesmo tempo, sente saudades da patroa, pretendendo até rever a filha dela. Uma contradição?

A segunda pergunta suscitada é a seguinte: o que significa sinceridade? Essas três pessoas expressaram exatamente o que sentiam? Percebi ao longo do tempo nessa pesquisa que a forma de alguém se certificar da sinceridade de outro foi tentando perceber se os afetos expressos realmente se referiam a algo íntimo. Como se houvesse um cerne, um centro das emoçóes em cada sujeito. Uma subjetividade única.

Agrado sentia, ao mesmo tempo, saudade e demérito. Quis chamar atenção para como essas questóes lembravam os debates sobre o self. ${ }^{8}$ Pretendi, nesse momento, tratar de uma análise mais detida entre o discurso oficial e a prática social sobre as emoções. $\mathrm{O}$ foco foram os discursos sobre os sentimentos nos espaços das audiências. Pretendi entender como juízes, advogados, domésticas e patroas simbolizaram essa relação. E, mais propriamente dito, qual o espaço reservado às emoçóes nas audiências desse tribunal.

Nesse sentido, David Le Breton (2009) me ajudou a relativizar a dicotomia entre razáo e emoção. $\mathrm{O}$ autor assinala que mesmo as atitudes mais racionais são motivadas por valores, significações e expectativas. De outro lado, é conhecido como a afetividade e os sentimentos carecem de uma racionalização. As pessoas racionalizam suas emoçóes, por exemplo, para controlá-las. Impossível entender, assim, razão e emoção como esferas distintas e incomunicáveis da vida. No caso observado, de Agrado e Huma, foi visível como essa divisão é problemática.

No mesmo sentido, Ricardo Benzaquen de Araújo e Eduardo Viveiros de Castro (1974) chamaram atenção para a suposta dicotomia entre as relaçôes afetivas e as de obrigaçóes. E o fizeram relacionando essa problemática ao ideário do individualismo. Explico: as relaçóes afetivas estariam no campo da opção individual, da escolha. A elas se oporiam o outro grupo de relações, a de obrigaçóes. Essas últimas seriam dirigidas por códigos exteriores ao indivíduo. Ou seja, existiriam um eu individual, centro de sentimentos e paixóes, e um eu social, enredado por deveres e direitos.

Esses autores chamaram atenção para a obra de Marcel Mauss. Apontaram para a base social das emoçóes. Mauss (2011) estudou sobre a percepção social destas. Ele analisou inúmeros casos em que a coordenação de três elementos se faz presente para a explicação dos sentimentos. Fez referência expressa ao corpo, à consciência individual e à coletividade na sua 
interpretaçáo dos sentimentos. O ser humano como um todo deveria ser considerado um todo biopsicossocial, e náo apenas um self que se deixaria conhecer pelas emoçóes mais íntimas.

Mauss (2011) fez referências às etnografias realizadas por outros na Polinésia e na Austrália. Para exemplificar, mencionou importantes casos de homens que, acreditando terem pecado, se deixavam morrer, às vezes no exato momento planejado ou previsto. Como se o desacordo entre sociedade e indivíduo lhe tirasse a razão da vida. E ele não mencionava um suicídio. Antes, era fato corriqueiro, num mundo em que a natureza social e moral é soberana ao corpo.

Para melhor compreensão, retorno ao texto de Ricardo Benzaquen de Araújo e Eduardo Viveiros de Castro (1974). Segundo os autores, essa dicotomia entre indivíduo emocional e indivíduo social gerou uma série de outras supostas oposiçóes. Uma dessas foi muito importante para o presente estudo, trata-se da questão do afeto em oposição ao direito. As relações jurídicas entre os indivíduos eram vistas como contrapostas às facetas da vida não redutíveis a elas. Há um problema nessa divisão, prosseguem os autores. Ela oscila entre ser uma concepção ideológica e uma constatação objetiva. Ou seja, ou bem se trataria de uma acepção desejada, um valor de determinada sociedade; ou bem se trataria de um dado etnográfico. Essa confusão estabelecida foi uma questão.

Partindo dessas consideraçóes, da necessidade de não se separar os afetos do direito, pretendi analisar esses fatores na minha pesquisa de campo. Realmente, realizar essa pesquisa sobre as audiências entre empregadas domésticas e patroas significou a escolha de um campo rico para o debate mencionado. Inúmeras foram as expressóes de afetos, emoçōes e sentimentos.

\section{Lágrimas e rupturas}

Desde o primeiro momento da pesquisa, percebi a oposiçáo entre cenas e bastidores (GOFFMAN, 2013; BERREMAN, 1990). Essa ideia foi útil, dado que eu estava numa cena, nas audiências, tentando compreender, também, como aqueles nativos representavam o que viveram nos bastidores. Existiam barreiras de percepção entre a cena da audiência e os bastidores, entre as relaçóes pouco a pouco construídas, às vezes durante anos, nas diversas relaçóes entre patroa e empregada.

A cena se repetia muitas vezes. As partes, doméstica e patroa, chegavam à sala de audiência, sentavam-se à mesa e não se entreolhavam. Evitavam olhar diretamente nos olhos uma da outra. E, quando isso ocorria, logo traçavam outro rumo para seu olhar, como quem estivesse diante de um inimigo. Entre elas havia um grande silêncio, contrastando, muitas vezes, 
com muito barulho na sala. Era impressionante ver um olhar conotando tanta frieza.

As domésticas e as patroas estavam sentindo muitas emoções, algumas choravam, outras se lamentavam, mas a regra era a de náo trocar olhares. Foi muito difícil compreender essa dinâmica no início da pesquisa. Muitas patroas ou empregadas saíam das audiências tristes, e eu nunca entendia o motivo, dado que, em várias vezes, a meu ver, tratavam-se de bons acordos.

As lágrimas também foram questão de estudo para Vincent-Buffault (1988). Ela quis compreender a importância das lágrimas nos romances e correspondências do século XVIII. Interpretou esse fenômeno como uma espécie de discurso que circula, formando uma verdadeira economia das lágrimas. Esse substantivo não era apenas expressão de um sentimento; antes, significava o estabelecimento de deveres e direitos. Lágrimas eram trocadas, dadas; deviam-se lágrimas. Elas firmavam várias relaçôes em que o choro era também ato de compadecimento, configurando assim uma verdadeira circulação de discursos.

Ou seja, a autora pesquisou as lágrimas como discurso, explicando como, a partir delas, se produziam realidades sociais. As importâncias eram múltiplas: regular os direitos e deveres, dar medida dos sentimentos entre os amantes, compadecimento com desconhecidos e, por fim, criar espaço imaginário singularmente distribuído. Existiu toda uma retórica das lágrimas nesse período, compreensível para os leitores da época. Eram comuns manifestaçôes espetaculares, hiperbólicas, uma abundância de secreçôes.

A falta de reciprocidade era tida como um drama ou algo desumano. Nesse sentido, em diversos espaços, as lágrimas compartilharam signos de emoçáo. Havia, inclusive, um fenômeno de contágio, numa legibilidade quase teatral, responsável por uma circulação sensível em vários níveis.

No meu trabalho de campo, também percebi como o discurso das lágrimas ganha outros significados. A abundância da secreção já não é mais comum. Embora o choro discreto não fosse regra, ele tinha alguma constância no trabalho de campo. Não era incomum ver o choro circunspecto, durante ou após a audiência. Às vezes, havia até o choro com parentes ou amigos que acompanhavam. Compreendi que era um discurso que promovia práticas sociais. Além de simplesmente expressá-las, ele gerava um verdadeiro expurgo do sentimento de ser "quase da família".

Havia, ainda, mais um detalhe sobre as lágrimas no espaço do tribunal. Existiam dois momentos específicos, envolvendo a retórica das lágrimas. $\mathrm{O}$ primeiro ocorria durante as audiências, já que elas tinham a capacidade de mudar o acordo, agindo como uma comunicação com o juiz. Segundo os advogados, inclusive, havia uma praxe de instruir as partes a parecerem tristes e até mesmo chorar. Ou seja, existia todo um comportamento esperado. 
O outro instante do choro fazia referência a um grupo de patroas e a um grupo de domésticas. Era um momento posterior à audiência. Geralmente, tinha lugar na sala de espera ou em alguma parte do corredor. Tratava-se de uma ou mais pessoas que se juntavam e se consolavam. Interessante perceber como outros valores, tais quais amizade, companheirismo, circulavam nesses momentos.

Segundo a teoria de Goffman (2013), a primeira representação poderia ser chamada de polidez, enquanto a outra, de decoro. A diferença é que na polidez o sujeito atua com palavras ou gestos com o intuito de se comunicar com a plateia, no nosso caso, com o juiz. No decoro, o sujeito age como quem está sendo observado, mas não empenhado em comunicar-se com uma plateia.

Certa vez, conversei com uma patroa, e ela me explicou essa dinâmica dos sentimentos nas audiências. Era uma tarde de fevereiro de 2014. Perguntei como ela se sentia. Ela me disse, em tom de desabafo:

Eu me senti muito mal aqui na justiça, me senti traída, porque eu a tinha como uma amiga. Pior do que o diagnóstico de câncer foi vir aqui. Não era necessário. Não dá pra confiar em ninguém. Em ninguém. Ela podia ter pedido, eu dava, mas ter me botado na justiça, não. Não dá pra confiar. Mas estar aqui é bom que acaba com isso tudo.

Outra vez, conversando com uma empregada doméstica, ela me disse uma frase marcante, cujo conteúdo se parece com essa fala da patroa. "Se eu me sentia da família? Lógico. Mas aqui, quando eu sentei naquela cadeira, eu tive a certeza que não era nada da família. Tinha certeza que essa ingenuidade acabou quando sentei."

Demorei algum tempo para perceber a mesma forma da retórica dos sentimentos naquele contexto do trabalho de campo. $\mathrm{O}$ meu raciocínio lógico e cartesiano foi aos poucos desconstruído pelas conversas com as domésticas e patroas após as audiências. Entendi, com o tempo, a dor de rememorar, reviver situaçóes. Muitas vezes, testemunhas contavam o que viram, trazendo à memória das partes cenas passadas, humilhações, rancores. Tudo isso era maximizado pelo simples fato de estar numa audiência, na justiça. Ou seja, deslocava-se uma questáo afetiva para o judiciário, que é um local sempre visto como de cobranças, de mal-estar.

Além disso, percebi como esses sujeitos ressignificaram o espaço da audiência. A cena do judiciário, racional, com seus ritos estabelecidos, era conhecida para mim. A minha surpresa foi ver além dessa cena, entender as barrei- 
ras de compreensão e os bastidores. Neles, havia um sentimento de ruptura, ou, pelo menos, de certeza do fim de uma relação íntima. Por isso a tristeza da doméstica em não poder mais ver a filha da patroa. A relação findou-se.

Mas seria tudo isso fruto de uma simples representação, no sentido usado por Goffman (2013)? Essa pergunta é crucial antes de avançar para outras questóes. Para respondê-la, introduzo nesse texto uma nova personagem, Carmen.

\section{O caso de Carmen}

Numa das minhas visitas a campo, presenciei certa audiência muito interessante. Tratava-se de um processo antigo, proposto por uma doméstica em 2010. No segundo semestre daquele ano, houve um acordo homologado pelo juiz. A patroa, no entanto, deixou de pagar as últimas parcelas. Nesse dia, estavam presentes, além da juíza, apenas a empregada e o seu advogado. A antiga patroa não compareceu. Após a rápida audiência, procurei pela empregada nos corredores do tribunal.

Essa doméstica resolveu conversar comigo, sendo extremamente solícita. Trabalhou como diarista e empregada doméstica durante toda a sua vida, desde os seus dez anos. Segundo ela, em todas as casas foi humilhada. Diz ainda ser muito penoso o ofício de doméstica. Diferentemente de muitas pessoas entrevistadas no campo, nunca se considerou "da família". Logo a informei que sua percepção parecia diferente de muitas domésticas e patroas. Ela disse tratar-se de uma ingenuidade das pessoas. Informou-me que, atualmente, prefere ser diarista. Perguntei o porquê dessa preferência. Ela me afirmou que o convívio entre patroa e empregada doméstica é negativo justamente pelo vínculo de afetividade formado.

Realmente era um padrão observado por mim as empregadas serem pessoas íntimas dessas famílias. Na verdade, o grau de intimidade variava, sendo certo que era mais forte entre as empregadas domésticas que dormiam no trabalho. E, menos visível, no caso das diaristas. $\mathrm{O}$ que eu não imaginava é que nem sempre esse convívio era representado como amigável. Por vezes, como no caso de Carmen, acordavam-se prestaçóes e contraprestaçóes que vão além daquilo estipulado pelo direito. A patroa dela a chamou para ser cuidadora de seu bebê. O seu papel era cuidar de uma criança, em troca disso receberia mensalmente um salário mínimo, contudo não teria sua "carteira assinada". Desenvolveu-se uma relação entre Carmen e essa família. Segundo a doméstica, um "apego maldoso". Uma "intimidade que faz mal". Contou que, com o tempo, passou a também fazer faxinas, passar roupa e cozinhar. Queixou-se de ficar sobrecarregada, queixa recorrente das empregadas domésticas. 
O sentimento de ser "quase da família" foi explorado por Maria Betania Ávila (2008) e por Fernando Cordeiro Barbosa (2000). A autora associa essa expressão à família brasileira e burguesa, tipicamente patriarcal, com a existência de criadas que cuidam de várias geraçóes. Já o antropólogo Fernando Barbosa apontou uma duplicidade da condição das domésticas em sua etnografia. Ao mesmo tempo que eram parte da família, eram também prestadoras de serviço àquele núcleo. Muitas vezes, essas mulheres dividem o cotidiano dos seus empregadores. Elas, por exemplo, sofrem juntas com seus patrôes por doenças e mortes nessas famílias. Um outro aspecto levantado pelo autor é a diminuição de contato com seus pais, maridos e filhos, com a sua chamada "família de origem". Dessa forma, quando as domésticas de minha pesquisa falavam em "quase" ser da família, se referiam a esse tipo de inclusão, precária, na família empregadora.

Carmen sabia que não era da família, embora fosse de uso corrente a adjetivação "quase da família". Novamente, a pergunta inicial ressurge. Tratava-se de uma representação? Será que ela era uma pessoa que usava máscaras? E a sua patroa? Mentia o tempo todo para conseguir confiança? Difícil entender essas perguntas em termos tão maniqueístas. David Le Breton (2009) nos permite compreender além de um self de Carmen, para entender uma pessoa capaz de sentir emoçóes diferentes, por vezes contraditórias.

Se nos prendêssemos à interpretaçáo do mundo conforme a de certos autores, tratava-se de uma mulher que colocava suas máscaras nas diversas cenas da vida cotidiana. Uma máscara para sua patroa, outra para seu filho, e outra, ainda, para seu médico. Para esse raciocínio, cada cena da vida cotidiana era representada com auxílio de um disfarce. Por trás de todas as camuflagens, havia o self de Carmen, ou seja, o que ela verdadeiramente pensava, sentia, suas verdadeiras emoçóes.

Le Breton (2009) explica que, por muito tempo, conceberam-se as ditas verdadeiras emoçóes como o centro do self. Como se Carmen só pudesse estar representando. $\mathrm{O}$ autor iniciou seu texto no sentido de demonstrar como a oposição entre razão e emoção é falsa. Afinal, na mais inteligível das açóes há elementos de afetividade, enquanto na mais afável das demonstrações de sentimentos há o mínimo de inteligibilidade.

Não era uma questão de debater se Carmen sentia isso ou aquilo. Mas de entender que é difícil não imaginar que em algum momento ela não se sentisse "da família". E que o seu "sentir-se da família" era concomitante ao sentimento de "não se sentir da família". Não existia outra explicação para a imensa tristeza e choro de algumas domésticas após a audiência, numa situação muito reservada com amigos e parentes. A troca de dádivas entre a patroa e Carmen pôde muito bem explicar essa situação. 
Essa prestação mais do que material me recordou a teoria de Marcel Mauss (2012). O autor pode nos ajudar a entender essa relação específica da doméstica com seu empregador. De forma distinta de outros contratos de trabalho, segundo observado por mim nessa pesquisa, quem contrata uma doméstica não espera apenas alguém para passar a roupa, varrer a casa ou limpar as janelas. Espera-se, para além, o afeto, o cuidado e a dedicação. Desenvolveram-se, naturalmente, muitas amizades. Mauss elaborou uma teoria sobre a importância da retribuição e da dádiva, tanto nas sociedades arcaicas quanto nas nossas sociedades.

O estudo do caso de Carmen pode trazer luz para outras questóes ligadas à reprodução. Mulheres como ela cozinham, passam, faxinam para que outras pessoas possam se dedicar ao trabalho dito produtivo. Carmen é, então, responsável pela reprodução. Já há algum tempo a literatura dos estudos de gênero vem problematizando o sentido reprodutivo do trabalho doméstico. Gayle Rubin (1975), por exemplo, aborda essa temática. A autora retoma às obras de Marx e Engels para explicar o sentido do trabalho reprodutivo. Em curtas linhas, para aquele, o único objetivo do sistema capitalista é a criação e a expansão do capital. E essa dinâmica se centra na transformação de dinheiro, pessoas e coisas em capital. E a expansão desse último é umbilicalmente ligada à extração da mais-valia, incorporando esse trabalho não pago ao próprio capital.

Desse modo, mais adiante a autora explica como o salário é determinado como o necessário para manter o trabalhador em atividade. Tanto para reproduzi-lo no cotidiano quanto para a reprodução do conjunto da força de trabalho de uma geração à outra. Reproduzir a mão de obra é, portanto, atividade importante para o sistema capitalista. O salário compra itens importantes para essa reproduçáo, como comida e roupa. Contudo, essas mercadorias não são consumidas tal como são compradas. Elas dependem de atividades para serem utilizadas. A comida deve ser cozida. A roupa deve ser lavada e passada.

O trabalho doméstico é uma das peças fulcrais para manutenção do próprio capitalismo. Sendo esse trabalho central na extração da mais-valia e da reprodução da força de trabalho. As mulheres são assim articuladas no nexo global do trabalho por meio dessa dinâmica. Para Marx, o valor dessa força de trabalho depende de um elemento histórico e moral. A autora afirma esse último elemento como central na dinâmica de gênero no trabalho reprodutivo. Outras autoras, Pearse e Connell (2014) também afirmam a presença maciça das mulheres nas atividades da reprodução.

Entre nós, a entrada das mulheres para o mercado formal de trabalho não significou a divisão mais igualitária dos trabalhos domésticos entre homens e mulheres. Nesse sentido, Bruschini e Lombardi (2000) lembram 
o caráter bipolar do trabalho feminino no Brasil. As autoras apontam para uma quantidade expressiva de mulheres em dois polos da atividade econômica. Por um lado, é perceptível a expressiva quantidade de mulheres engenheiras, arquitetas ou médicas. São profissóes marcadas pelos bons rendimentos, altos índices de formalização e de proteção do trabalhador. Essa realidade contrasta com outro polo das atividades econômicas: o setor de trabalho doméstico remunerado, marcadamente precário. Note-se que esses dois polos são complementares, uma vez que as empregadas domésticas e diaristas realizam o trabalho antes realizados por essas novas engenheiras, arquitetas e médicas. Lembrando artigo de Helena Hirata (2004), perpetuou-se o caráter feminino da domesticidade por meio da criaçấo de um lugar comum associando reprodução às mulheres.

Outros questionamentos podem ser levantados lembrando a história de Carmen. A diferenciaçáo entre diarista e empregada doméstica é uma delas. Para o direito, essa divisão não é clara. Não há uma uniformização nacional dessa regra entre os tribunais. Para além dessas questôes jurídicas, Alexandre Barbosa Fraga (2010) estudou o trabalho doméstico remunerado no Brasil e, principalmente, na cidade do Rio de Janeiro. Utilizando-se de pesquisa quantitativa e qualitativa, demonstrou a forma como as próprias nativas se definiam como empregadas domésticas ou diaristas. Vários são os critérios levados em conta, entre eles número de dias trabalhados e forma de pagamento.

Como o presente artigo foca no estudo das emoçóes, quero mencionar um desses critérios: a afetividade. Era exatamente isso que Carmen queria dizer quando afirmou preferir ser diarista, por conta do vínculo formado. Aos poucos, com minha pesquisa fui construindo dados sobre esse tipo de "cuidado" estabelecido entre patroas e domésticas. Ele é mais forte nos casos em que a empregada doméstica dorme no serviço. E é menos marcado com as diaristas. É certo que não se trata aqui de uma noçáo fixa como blocos monolíticos, mas sim de identidades muito mais maleáveis e transformadas por rupturas e continuidades ao longo do tempo.

\section{"Cuidado": verbo ou substantito?}

O fato de contratar uma doméstica significa um curioso circular de valores. Muitos autores trabalham nessa perspectiva (PIRES, 2013; APPADURAI, 2008). William Davenport (2008) desenvolveu uma etnografia na Ilha de Santa Catalina, também chamada Aoriki, situada nas Ilhas Salomão Orientais. Ele estudou como uma série de trocas de mercadoria, ou seja, relaçóes jurídicas, foram cruciais para manutençáo das relaçóes sociais. 
Nessa comunidade, existe toda uma distribuição de riqueza quando da morte de algum integrante. O prestígio de uma pessoa era tão maior quanto mais enredado em uma complexa rede de créditos e dívidas estabelecida por essa ocasião. Além disso, a cada década é realizada a munira, uma cerimônia que demanda supremo esforço econômico e mesmo físico dos habitantes. Eles chegam a passar anos planejando essa grande homenagem aos seus mortos. $\mathrm{O}$ resultado, ao final, do ponto de vista econômico é, por exemplo, a construção de grandes canoas, como a grande canoa mercante. O país é conhecido internacionalmente pela construção dessas embarcações. Uma relação de certo modo econômica e que faz circular valores sociais.

Assim também o pagamento de uma doméstica faz circular valores sociais. Recordo-me de dois casos contados por juízes em entrevista. Uma empregada doméstica propôs reclamação trabalhista pleiteando vários décimo-terceiro salários que a empregadora náo pagou. No dia da audiência, a defesa da patroa trouxe comprovantes de depósitos bancários em poupança. Ela dizia não ter pagado nas mãos da empregada, mas ter depositado os valores numa poupança, sem a ciência da empregada. Poupança essa que estava no nome da sua empregada. Esse foi um exemplo da circulação do valor do cuidado. Ou seja, se de alguma forma a empregadora pensou no futuro da empregada, ela também a cerceou do direito de usufruir de sua própria remuneração. Uma espécie de cuidado mais parecido com a tutela de uma criança, como se se tratasse de alguém sem a mínima competência para gerir a própria existência. $\mathrm{O}$ salário era da empregada, mas ela dele não podia dispor.

Outro caso foi o de uma empregada doméstica que trabalhou muitos anos para um casal de idosos. Ocorreu que, dada a idade avançada, o senhor morreu, ficando a patroa viúva. Ela se envolveu com um rapaz jovem, de vinte ou trinta anos, e queria casar-se novamente. Resolução à qual se opuseram suas filhas e sua empregada doméstica. Por algum motivo, a empregada doméstica resolveu ir à Justiça do Trabalho contra sua patroa. As filhas da patroa pagaram o advogado da doméstica. E, para terminar a cena, o rapaz estava presente, observando a audiência na plateia. Muito provavelmente, a doméstica de alguma forma se sentia cuidando da sua patroa já idosa.

Utilizo a terminologia "cuidado", uma vez que os próprios juízes, nativos do meu campo, a mencionaram. Curiosamente, muito se falava em "cuidado", mas nunca como o particípio do verbo cuidar, como uma ação desprovida de qualidade. Sempre se reportava ao termo como um substantivo. Era um valor quase material, de tão central nas narrativas. A empregada cuidava da família empregadora. A patroa cuidava da empregada. $\mathrm{O}$ 
Juiz cuidava da causa. O termo deu inclusive nome a duas ocupaçóes, os cuidadores de criança e de idoso. Mas que tipo de cuidado é esse?

O desapego pelas regras formais de convivência, a indistinção entre público e privado e o caráter emocional eram os valores que circulavam com essa relação. Sérgio Buarque de Holanda (1995) faz alusóes a essas características para enfatizar o que chamou de "homem cordial". Assim, as leis são ignoradas em favor das amizades. O caráter emocional retratado pelo autor também deve ser levado em conta para compreender esse campo. Quem age com a cordia, com o coração, é, ao mesmo tempo, capaz do maior gesto de carinho e do maior ato de intromissão na vida alheia.

Vários são os profissionais envolvidos nesse sentido da expressão "cuidado" das pessoas. Além dos profissionais da saúde, como médicos, enfermeiros, psicólogos, desenvolveram-se várias profissões ligadas ao ato de cuidar das pessoas. Por exemplo, assistentes sociais, religiosos, professores, pedagogos e educadores. Chiara Pussetti (2010) estudou as diferentes formas de cuidado da psiquiatria com imigrantes em Portugal. A autora traz ao texto muitas questôes. Quero atentar-me ao fato de esse tipo específico de cuidado ser tratado como uma intromissão. Isso é muito frequente não apenas na relação entre patroa e empregada, mas também na relação entre juiz e partes.

No processo de Carmen foi feito um acordo. Isso, certamente, não é uma exceção. Segundo muitas conversas com vários advogados trabalhistas no campo, além de alguns juízes, o número de acordos na Justiça do Trabalho foi elevado. Um quadro jurídico muito peculiar levava todos os contendentes, nas audiências sobre domésticas, a preferirem o acordo. Quase todos, diria. A exceção, repetidamente observada em campo, era da própria doméstica. Mas de fato a doméstica pretendia acordar? $\mathrm{O}$ afeto podia ser objeto de conciliação??

Quero regressar à relação específica do trabalho doméstico, remetendo-me ao trabalho de Maria Claudia Coelho (2013). Ela estudou as trocas de presentes entre patroas e empregadas domésticas na Zona Sul da Cidade do Rio de Janeiro. Entendeu a gratidáo pelos presentes dados pelas patroas às empregadas como um reforço dos vínculos hierárquicos. Por outro lado, a ingratidáo, representada pelo ressentimento ou pela indiferença, pareceu-se com uma insubordinação.

Essa mistura de amizade e de hierarquia pareceu estranha a outras culturas. Como compreender o mito fundador de Romeu e Julieta sem a distinção entre ordem e paixão? Conforme Benzaquen de Araújo e Viveiros de Castro (1974), eles abandonaram a família para viver seu amor. Isso foi uma representaçáo importante na contemporaneidade. Eles eram definidos por seu grupo social, por sua família. Contudo, o amor despontou como uma lógica de uma relação de livre escolha individual. Nela não 
cabia falar no elemento da hierarquia. A pessoa amada seria escolhida pelo indivíduo e não por sua família.

Assim, para o ideário do liberalismo clássico, afeto se distanciou das relações de obrigação ou de direito. Entre as domésticas e as patroas, como visto, essa não era a regra. $\mathrm{O}$ afeto e as relações de uma obrigação contratual se entrelaçavam com significativa confusão. Muitos juízes falavam que eu deveria comparar a atividade de julgar um processo de domésticas com um divórcio na Vara de Família.

Em muitas audiências, percebem-se elementos de intimidade nos discursos dos juízes, dos advogados, das domésticas e das patroas. Em outras sociedades, como a norte-americana, a conexão entre intimidade e dinheiro podia ser problemática. Segundo Zelizer (2011), nos Estados Unidos, a concomitância da condução de atividades econômicas e das relações de pessoalidade era reputada por muitos como incompatível.

Nos tribunais desse país, existe toda uma crença de que a intersubjetividade corrompe a economia e vice-versa. Esse argumento era geralmente usado pelos tribunais americanos. A autora faz alusão à tese de que intimidade e negociação fazem parte de "mundos hostis" que não devem se misturar. $\mathrm{O}$ contato entre os mundos traz contaminação moral segundo essa ótica. Seu livro abordou três questôes centrais. A primeira foi investigar a maneira pela qual as pessoas combinam economia e intimidade. Além disso, visou compreender por que o sistema jurídico dos EUA (ou seja, advogados, juízes, tribunais, juristas e jurados) negociava a coexistência de relações íntimas e reivindicações econômicas.

O seu empreendimento foi realizado a partir de processos judiciais específicos para explicar como o sistema judicial lidou com a delicada relação surgida em litígios acerca da interseção entre vida íntima e transações econômicas. Sua questáo é como essa arena jurídica se comportou frente a isso. A prática jurídica trouxe importantes dados sobre essa problemática.

Mais adiante, a autora explicou que, na prática, essas esferas da vida não eram segregadas pelos tribunais. Esses apenas participavam de um processo de escolha de combinaçóes entre certas formas de intimidade com particulares transaçóes econômicas. Nesse sentido, Zelizer relatou um caso interessante. Especificamente sobre trabalho doméstico remunerado, a autora descreve aquele que alguns chamaram de "o maior caso de indenização paga por trabalho doméstico remunerado nos Estados Unidos".

Trata-se do caso de Gabina Camacho Lopez contra a família Rodriguez, julgado em 1980 pelo Tribunal Regional do Distrito de Columbia. Eles a contrataram, ainda na Bolívia, e a levaram para Washington D.C. Gabina permaneceu nessa cidade como imigrante ilegal e sem conhecimentos da língua inglesa. Ela jamais saiu da casa dos Rodriguez, durante 
alguns anos. Eles a disseram que estavam depositando seu pagamento num banco. Depois de três anos a empregada exigiu pagamento. No entanto, eles se recusaram a entregar o dinheiro.

Gabina, então, procurou o judiciário com base no Fair Labor Standards Acts, em busca de seus salários não pagos. Naquele tribunal, o debate foi se ela era realmente uma empregada. Tese abraçada pelos seus advogados e rechaçada pelos Rodriguez. Mesmo recusando os pedidos de horas extraordinárias, a justiça foi enfaticamente favorável à empregada. Ficou registrado naquela sentença que essa família usou de má-fé ao não cumprir o mencionado $A c t$, além de explorar uma indígena, imigrante, jovem e com pouca instrução.

Convém, agora, uma breve comparaçáo. Os tribunais norte-americanos estavam preocupados em distinguir os tipos de cuidados, se foram lícitos ou ilícitos. E, para além, como eles se relacionavam com valores econômicos. Sua intençáo era sempre a de separar o mundo afetivo do financeiro, quando a moral assim determinava. Entre nós, no entanto, o quadro era muito diferente. Não foram julgadas por essa premissa nem Agrado, nem Carmen, nem nenhuma das domésticas dos muitos casos acompanhados por mim.

É muito curioso como entre nós a intimidade e a negociação se misturam sem nenhum tipo de constrangimento. Isso ficou latente em meu trabalho de campo. Certa vez perguntei a duas juízas, em momentos distintos, em entrevistas separadas, a mesma questão: "Esse tipo de relaçáo e esse tipo de audiência são emocionais ou são técnicos?". Recebi duas respostas distintas. A primeira me disse: "Não, meu filho, você está enganado. Não tem nada de técnico aqui, é tudo emoção". A outra me respondeu: "Olha, a relação é emocional, claro. Mas o julgamento não, esse é técnico".

Essas juízas afirmaram tratar-se de uma relação com intensos envolvimentos afetivos. E isso não foi levado em conta. Entre nós, não foi importante o tipo de relação afetiva ou se houve algum "cuidado indevido". Muito pelo contrário, preocupou-se em compreender apenas se há "verdade" nas declaraçóes. Não importa como se desenrolou a relação. Até mesmo porque é de se supor que esse envolvimento entre patroa e empregada, conforme fala dos nativos, reproduzisse uma confusão entre os mundos público e privado. Um fator que, extrapolando o tempo de existência dessas atividades, reaparecesse nas audiências.

\section{Eva, Maria e a rhetoric of control}

Durante a pesquisa, entrevistei algumas donas de casa sobre suas relaçôes com as trabalhadoras domésticas. Apenas encontrei mulheres nessa posição. Nenhum homem figurou como réu nas açôes que acompanhei. 
As domésticas sempre propuseram suas ações judiciais contra as patroas, nunca contra os patróes. Esse fenômeno muito me lembrou de que, nas audiências sobre doméstica, apenas figuravam mulheres como reclamantes. Não vi nenhum "empregado doméstico".

Tudo isso ajudou a entender como essa relação específica perpassa o espaço doméstico e chega ao tribunal. $\mathrm{O}$ caso de Eva pôde ilustrar isso. Ela é uma senhora, católica, com aproximadamente cinquenta anos de idade. Conversando comigo, falou que eu tenho que tomar cuidado para "não focalizar apenas um lado da moeda”, querendo dizer que precisava ouvir as empregadoras domésticas também.

Percebi um dado interessante. Segundo Eva, em sua casa, quem trata da parte de pagamento da empregada é seu marido. Esse casal estabeleceu isso em conjunto, mesmo sendo incomum entre suas amigas. Ela sinalizou ser menos desgastante, para os homens, controlar essa relação. Afirmou que sua empregada doméstica, mesmo tendo uma casa própria, dorme num dos quartos de seu apartamento. A Carteira de Trabalho e Previdência Social (CTPS) foi assinada, mesmo quando isso era fato raro. Seu marido sempre cuidou do conforto da empregada, providenciando, inclusive, um ponto de TV a cabo em seu quarto. Pagando a contribuição ao INSS mesmo quando a lei ainda não obrigava.

O marido de Eva foi imaginado, naquela relação, como a pessoa mais indicada, menos sentimental. Mesmo assim, ele jamais pediu recibo ou comprou um caderno de ponto. Eva mencionou tal fato como uma reprovação ao seu marido. Na sequência, mencionou um parente seu muito "caxias, certinho", que controlava ponto e pegava os recibos. Mas deu a entender ser isso uma exceçáo. A reprovaçáo do ato de seu marido de náo pegar recibos foi colocada.

Ou seja, a relação entre gênero, emoções e perigo foi ressaltada. O casal entendeu que a parte mais adequada para pagar a empregada era o homem. Dado que o a mulher é "mais afetiva". E que "os afetos são de difícil controle". A própria mulher entendeu que "não conseguiria controlar suas emoçóes". E, ainda por cima, reprovou o marido que também não conseguira dominar as emoçóes, sem fazer um caderno de ponto ou pegar recibos. Como se a afetividade fosse rejeitada, um sinônimo de fraqueza, tipicamente feminina.

Outras pesquisadoras se dedicaram à relação entre sentimentos e trabalho doméstico. Helena Hirata (2004) lembra um discurso muito repetido de que a atividade doméstica não é trabalho e que deve ser desenvolvida por "amor". Essa ideia, situando no mesmo campo afetividade e trabalho, contribui para a sujeição feminina, uma vez que mantém a condição subalterna dessas mulheres. Encarnación Gutiérrez-Rodríguez (2013) estu- 
dou as empregadas domésticas imigrantes na União Europeia. Da mesma forma entendeu, no discurso dessas atividades, como trabalho afetivo uma forma de retificação de um padrão heteronormativo. Assim, no seu campo empírico, aos homens é resguardado um lugar de visibilidade e importância, sustentado pela invisibilidade das mulheres.

$\mathrm{Na}$ minha pesquisa, as empregadas sempre tinham medo de "não se segurar e falar demais, revelar coisas que não se deve", conta-me. Ela foi uma das primeiras domésticas entrevistadas na pesquisa. $\mathrm{O}$ advogado dela náo estava presente em sua audiência, razão pela qual ela foi remarcada. Percebi que ela ouvia mal e estava com dificuldade de se comunicar com a juíza. Era uma senhora aparentando ter pelo menos sessenta anos, acompanhada por outras amigas. Essas últimas náo queriam que ela falasse comigo.

Com jeitinho, eu me aproximei e consegui que ela conversasse comigo por alguns instantes. Falou que se sentia muito bem na casa onde trabalhou, contudo, ultimamente, vinha se sentindo cansada e sobrecarregada. Disse que se sentiu muito acuada naquela situação. "Me sentia desamparada na frente da juíza, mas Deus me ajudou". Ela tinha um medo enorme da figura do judiciário, a ponto de pedir para que o sobrenatural the guardasse.

A rhetoric of control, nesse caso, era latente. Essa ligação entre gênero e emoçóes também foi importante nos estudos de Catherine Lutz (1990). Para a autora, esse discurso foi reproduzido tanto fora como dentro do meio acadêmico ocidental. Frequentemente, os adjetivos usados para qualificar emoçōes foram usados para determinar o feminino. Então, esse discurso pôde ser, ao mesmo tempo, um discurso sobre gênero. $\mathrm{E}$ as emoçōes, tal como o feminino, foram associadas à natureza, nunca à cultura. As emoçóes seriam, assim, o centro do self, uma parte "natural" do ser humano.

Elas seriam caóticas, não ordenadas, incontroláveis e involuntárias. Ou seja, trataram-se as emoçóes como um processo desvantajoso se comparadas à cogniçáo ou à racionalidade. E, por extensão, o feminino estaria em desvantagem frente ao masculino, esse último sempre associado à razão.

Há ainda outra questão, para além dessa problemática entre natureza, emoção e feminino. Catherine Lutz (1990) tratou da identificação entre esse bloco de ideias e a noção de perigo. O que seria imperioso, incontrolável e involuntário, como a natureza, a emoção e o feminino, também seria perigoso. Em sua pesquisa, a autora se utilizou de uma série de entrevistas com homens e mulheres norte-americanos. Nelas, fica latente o que Catherine chamou de rhetoric of control. Ela se referiu, com esse termo, à necessidade, expressa pelos seus interlocutores, de um controle sobre as emoçóes, sobre o gerenciamento das emoçóes. Essa ideia diz respeito a uma certa narrativa de grupos dominados. 
Essa espécie de desorganização intrapsíquica foi ressaltada pelos nativos - advogados, juízes, empregadas domésticas e patroas. Todos eles tinham uma maneira muito especial de compreender o trabalho doméstico remunerado. Essas falas reproduziam e construíam uma imagem da feminilidade. Catherine Lutz mostrou que os discursos dos nativos de suas entrevistas, discursos muito próximos dos que eu ouvi no meu trabalho de campo, eram evidência de uma visão cultural largamente difundida sobre o perigo das mulheres e sua emotividade.

Esses discursos todos tinham relação com os escritos de Foucault sobre sexualidade, assevera a autora. Tanto a emotividade quanto a sexualidade são domínios reprimidos pelo modelo biomédico. Existiriam assim formas saudáveis e doentias de se vivenciar experiências sexuais e emocionais. Falar sobre emoções ou práticas sexuais controladas significa replicar as percepções de emoçóes e de sexualidade como algo natural, perigoso e irracional

E exatamente isso foi muito recorrente em meu campo, um discurso da necessidade de disciplinar as emoçóes. Como se as mulheres tivessem mais dificuldade de se conter. Isso contrastava com o imaginário daquelas pessoas sobre os homens. Eles teriam facilidade de desenvolver uma racionalidade capaz de separar questôes financeiras de questôes afetivas.

O pensamento de que essa configuração é natural, sendo o cuidado da casa uma propriedade das mulheres, foi debatido por Valdemir Zamparoni (1999). Trata-se de um pesquisador que se interessou pelo trabalho doméstico em Moçambique. E, nessa experiência, constatou coisas interessantes. Em Maputo, capital moçambicana, os empregados domésticos eram majoritariamente homens, e não mulheres. Durante a pesquisa de Zamparoni naquele país, ele contratou um empregado doméstico para realização dos afazeres do lar. Depois de contratado, porém, o seu empregado doméstico pediu licença para se ausentar do trabalho por um mês. Ele disse que precisava realizar um curso. A princípio, Valdemir pensou que fosse para realizar um curso de culinária. Contudo, ele havia se inscrito para receber formação militar das milícias populares em Moçambique. Findo o mês do seu curso, ele regressou à casa do pesquisador. Logo no primeiro dia, colocou uma metralhadora num canto junto com os pentes de munição. Trocou sua farda militar pelo seu avental branco e continuou o serviço.

Trata-se, com certeza, de uma divisão sexual do trabalho doméstico diferente da encontrada na minha pesquisa de campo em Niterói. As construções históricas explicam a prevalência masculina no trabalho doméstico remunerado em Moçambique e, em certa medida, na África Austral. O autor elencou razóes desse quadro estudando certos fatos ocorridos durante o colonialismo português. Havia, de forma difusa, a ideia de que o homem branco teria uma ilimitada sanha sexual. De um lado, as mulheres brancas 
não queriam seus maridos e filhos compartilhando o espaço doméstico com uma mulher negra. De outro, também, a divisão sexual do trabalho doméstico entre os negros apontava uma configuraçáo específica. As mulheres deveriam cuidar da roça, da vida doméstica e serem resguardadas para a procriaçáo. E aos homens negros eram destinados os trabalhos fora de casa.

Atualmente, como estudou Ruth Kélia Castel-Branco (2013), a situação é bem diferente. Profundas alteraçôes no cenário moçambicano, com a guerra civil, transformaram a divisão sexual do trabalho doméstico remunerado. Atualmente, as empregadas domésticas são mulheres em sua maioria. Eu gostaria apenas de frisar, como fez Margaret Mead (2000), que outras sociedades entendem a relação sexo/temperamento/funções de forma distintas de como nós entendemos. Trata-se, portanto, de uma construção cultural.

\section{Considerações finais}

As emoçôes não são bem recebidas no espaço do judiciário. Considera-se algo estranho alguém chorar numa audiência. Mas até o pranto tinha um motivo. A subjetividade se mostrava quase incontrolável ainda que se manifestando num espaço dito racional. O direito e a lei apareciam apenas quando essa familiaridade se rompia, como no caso de Carmen. A audiência significava o fim dessa relação entre pessoas "quase da família". Uma ruptura esperada. Não eram mais amigas, companheiras ou pessoas de confiança. O sentimento era outro, bem distinto. O desviar constante de olhares denunciava o mal-estar em rever essa pessoa, nessa circunstância.

A relação entre domésticas e patroas, como demonstrado, significa uma relação de trabalho única. Uma amizade na qual imperam elementos de hierarquia, desenvolvendo um tipo especial de cuidado. A ruptura dessa ligação pode ser dramática. Como percebi nessa pesquisa, esse drama é sempre relembrado no espaço do tribunal. Ouvir a fala das testemunhas, rememorar fatos, rever pessoas. Quase sempre essa dinâmica desperta sentimentos. Não por acaso eu presenciei tanto choro, palavras duras e pessoas tristes.

Trabalhei com a ideia de emoçôes como construtos sociais e discursivos. Essa realidade me obrigou a buscar a antropologia das emoçóes para compreendê-la. Afinal, se algo é marcante na relaçáo entre empregadas domésticas e patroas é a obrigatoriedade da harmonia. As domésticas são "quase da família". Entender a emoção como discurso foi útil para mergulhar nessas relaçóes. O papel das lágrimas nas audiências. O medo das empregadas domésticas diante do juiz. Todas essas questóes ganharam atenção neste trabalho. Não poderia deixar de refletir sobre as relaçôes de gênero e 
emoção. Os discursos de gênero sobre as mulheres apontavam para a obrigatoriedade de docilidade. O cuidado era lido como algo "naturalmente" feminino. Todos esses problemas foram, igualmente, abordados.

\section{Notas}

1. Tendo em vista a dificuldade de fiscalização e inspeção das condiçóes do trabalho nos lares pelos órgãos do Ministério do Trabalho e Emprego (CARDOSO; LAGE, 2007).

2. O tema central era o trabalho doméstico remunerado e as Varas do Trabalho de Niterói.

3. Tratou-se de algumas categorias usadas entre os nativos. Doméstica é um gênero. Diarista e empregada doméstica são espécies desse gênero. Enquanto isso, o termo patroa engloba as empregadoras domésticas e as pessoas para quem as diaristas trabalham. Comumente, no tribunal, há confusão entre diarista e empregada doméstica e entre empregadoras domésticas e outras pessoas para quem as diaristas trabalham. Também se confunde patroa com dona de casa, significando a mulher que desenvolve tarefas domésticas ou que paga para que alguma doméstica se desenvolva. Quando a doméstica, tal como qualquer trabalhador, postula em juízo na Justiça do Trabalho passa a denominar-se reclamante ou autora. E quando a patroa, tal como qualquer suposto empregador, é postulada em juízo recebe o nome de reclamada ou ré. Patroa e domésticas são partes nos processos.

4. Presenciei 200 audiências, das quais 37 eram sobre trabalho doméstico remunerado. As outras 163 audiências se referiam a processos judiciais de trabalhadores de outras categorias profissionais contra seus empregadores. Cabe ressaltar a importância metodológica da observação direta dessas 163 audiências. Assim procedi no intuito de produzir uma comparação entre esses dois grupos de audiências, contrastando-os. A ideia era colocar em relevo as especificidades dos processos judiciais das empregadas domésticas, investigando como os juízes, advogados e partes se comportavam especificamente nessas audiências sobre trabalho doméstico. Outra vantagem em acompanhar essas outras 163 audiências foi ter contato com os muitos advogados.

5. Trata-se de um bairro pauperizado da cidade do Rio de Janeiro, constituído por dezesseis comunidades e habitado por mais de 100 mil pessoas (WIMMER; FIGUEIREDO, 2006).

6. A Vila do João é uma das comunidades do Complexo da Maré.

7. Os nomes de todos os entrevistados foram mantidos em sigilo.

8. O conceito de self foi pensado por várias áreas de conhecimento. Para Goffman (2013), essa ideia tem ligação com um comportamento humano 
tratado como sua situação social, ou seja, tem relação com o modo como o indivíduo se apresenta para os outros.

9. O mecanismo das audiências é bem burocrático, tudo se desenrola em torno do acordo. Durante aquela primeira audiência de Carmen, o juiz começou com a pergunta: “Tem acordo?”. Eles eram comuns também em outras categorias, mas nas domésticas era quase a totalidade das que eu vi. Percepção compartilhada por juízes e advogados do campo. Os acordos se colocavam como forma especial e privilegiada de administrar esses conflitos. Carmen não negociou diretamente com a sua patroa. Longe de uma negociação entre as partes, tratava-se de uma dinâmica em que a figura do juiz é muito presente. Uma intervenção intrometida tal qual a exposta por Chiara Pussetti (2010).

\section{Referências bibliográficas}

ABU-LUGHOD, L.; LUTZ, C. Introduction: emotion, discourse, and politics of everyday life. In: Language and the Politics of Emotion. Cambridge: Cambridge University Press, 1990, p. 1-23.

APPADURAI, Arjun. A vida social das coisas. As mercadorias sob uma perspectiva cultural. Niterói: EdUFF, 2008.

ÁVILA, Maria Betania. Algumas questões teóricas e políticas sobre emprego doméstico. In: ÁVILA, Maria Betania et al. (Org.). Reflexōes feministas sobre informalidade e trabalho doméstico. Recife: SOS Corpo - Instituto Feminista para a Democracia, p. 65-72, 2008.

BARBOSA, Fernando Cordeiro. Trabalho e residência: estudo das ocupações de empregada doméstica e empregado de edifício a partir de migrantes "nordestinos”. Niterói: EdUFF, 2000.

BERREMAN, Gerald. Etnografia e controle de impressóes em uma aldeia do Himalaia. In: ZALUAR, Alba. Desvendando máscaras sociais. Rio de Janeiro: Livraria Francisco Alves, p. 123-174, 1990.

BRUSCHINI, Cristina; LOMBARDI, Maria Rosa. A bipolaridade do trabalho feminino no Brasil contemporâneo. Cadernos de pesquisa, v. 110, p. 67-104. 2000.

CARDOSO, Adalberto Moreira; LAGE, Telma. As normas e os fatos: desenho e efetividade das instituiçóes de regulação do mercado de trabalho no Brasil. Rio de Janeiro: FGV Editora, 2007.

CASTEL-BRANCO, Ruth. A formalização do trabalho doméstico na cidade de Maputo: desafios para o estado e organizaçóes laborais. In: FRANCISCO, Antonio et al. (Org.). Desafios para Moçambique 2013. Maputo: IESE - Instituto de Estudos Sociais e Económicos, 2013. p. 307-330.

COELHO, Maria Claudia; REZENDE, Claudia. Antropologia das emoçôes. Rio de Janeiro: FGV, 2013. 
CONELL, Raewyn; PEARSE, Rebecca. Gender: in world perspective (polity short introductions). Cambridge: Polity Press, 2014.

DAVENPORT, William H. Dois tipos de valor nas Ilhas Salomão Orientais. In: APPADURAI, Arjun. A vida social das coisas. Niterói: EdUFF, 2008. p. $125-142$.

FRAGA, Alexandre Barbosa. De empregada a diarista: as novas configuraçóes do trabalho doméstico remunerado. Rio de Janeiro, 2010. Dissertação (Mestrado) - Programa de Pós-Graduação em Sociologia e Antropologia da Universidade Federal do Rio de Janeiro.

GOFFMAN, Erving. A representação do eu na vida cotidiana. In: A representaçâo do eu na vida cotidiana. Petrópolis: Vozes, 2013.

GUTIÉRREZ-RODRÍGUEZ, Encarnación. Trabajo doméstico/ trabajo afectivo: sobre heteronormatividad y la colonialidad del trabajo en el contexto de las políticas migratorias de la UE. In: Revista de Estudios Sociales, Bogotá, n. 45, p. 123-134. 2013.

HIRATA, Helena. Trabalho doméstico: uma servidão voluntária. In Politicas públicas e igualdade de gênero. São Paulo: Coordenadoria Especial da Mulher, 2004. p. 43-54.

HOLANDA, Sérgio Buarque de. Raizes do Brasil. São Paulo: Companhia das Letras, 1995.

LE BRETON, David. As paixões ordinárias. Antropologia das emoções. Petrópolis: Vozes, 2009.

LUTZ, Catherine. Engerdered Emotion: gender, power, and rhetoric of emotional control in American discourse. In: ABU-LUGHOD, L.; LUTZ, C. Language and the Politics of Emotion. Cambridge: Cambridge University Press, 1990. p. 69-91.

MAUSS, M. Ensaio sobre a dádiva. Forma e razão da troca em sociedades arcaicas. São Paulo: Cosac \& Naify, 2012.

A expressão obrigatória dos sentimentos (rituais orais funerários australianos, 1921). In: Ensaios de sociologia. São Paulo: Perspectiva, 2011. p. 325-333.

MEAD, Margaret. Sexo e temperamento. São Paulo: Perspectiva, 2000.

PIRES, Lenin. Entre notas e moedas: trocas e circulação de valores entre negociantes em Constitución. Horizontes Antropológicos, v. 9, n. 39, p. 149-178. 2013.

POCHMANN, Márcio. Nova classe média? São Paulo: Boitempo Editorial, 2012.

PUSSETTI, Chiara. Identidades em crise: imigrantes, emoções e saúde mental em Portugal. Saúde e Sociedade, São Paulo, v. 19, n. 1, p. 94-113. 2010.

RUBIN, Gayle. The Traffic in Women: notes on the "political economy" of sex. In: REITER, R. Toward an Anthropology of Women. Nova York: Monthly Review Press, 1975. 
SAFFIOTI, Heleieth I. B. Emprego doméstico e capitalismo. Petrópolis: Vozes, 1978.

VINCENT-BUFFAULT, Anne. História das lágrimas. Rio de Janeiro: Paz e Terra, 1988.

VIVEIROS DE CASTRO, Eduardo; BENZAQUEN DE ARAUJO, Ricardo. Romeu e Julieta e a origem do Estado. In: VELHO, Gilberto. Arte e sociedade: ensaios de sociologia da arte. Rio de Janeiro: Zahar Editores, 1974. p. 105-130.

WIMMER, Gert Ferreira; FIGUEIREDO, Gustavo de oliveira. Ação coletiva para qualidade de vida: autonomia, transdisciplinaridade e intersetorialidade. Ciência \& Saúde Coletiva, Rio de Janeiro, v. 11, n. 1, p. 145-154. 2006.

ZAMPARONI, Valdemir. Gênero e trabalho doméstico numa sociedade colonial: Lourenço Marques, Moçambique, c. 1900-1940. Afro-Asia (UFBA), Salvador, v. 23, p. 147-174. 1999.

ZELIZER, Viviana. A negociação da intimidade. Petrópolis: Vozes, 2011.

autor Fábio de Medina da Silva Gomes

É Doutorando do Programa de Pós-Graduação em Antropologia da Universidade Federal Fluminense (PPGA/UFF). Pesquisador do Instituto Nacional de Ciência e Tecnologia - Instituto de Estudos Comparados em Administração Institucional de Conflitos (INCT-InEAC). Professor Substituto de Direito do Trabalho, Biomedicina e Perícia da Universidade Federal do Rio de Janeiro (UFRJ).

Recebido em: 17/05/2015 Aceito para publicaçáo em: 20/02/2016 